\title{
RESISTANCE EVALUATION OF MODERN RICE VARIETIES TO BROWN PLANTHOPPER Nilaparvata lugens STÅL
}

\author{
Eko Hari Iswanto, Dede Munawar, \& Rahmini
}

\author{
Indonesian Center for Rice Research \\ Jl. Raya Sukamandi 9 Subang West Java 41256 \\ E-mail: hariswanto@yahoo.com
}

Manuscript received: 1 July 2020. Revision accepted: 11 September 2020.

\begin{abstract}
Resistance evaluation of modern rice varieties to brown planthopper Nilaparvata lugens $S T A L$. The research was performed to understand the resistance of modern rice varieties to the field population of brown planthopper (BPH). The research studied BPH settling preference, numbers of laid eggs, and functional plant loss index (FPLI) of resistant and susceptible rice varieties. The results showed BPH were less settle and laid fewer eggs on resistant varieties. BPH significantly settled longer on TN1 than other varieties after 24 hours. The numbers of eggs laid on rice resistant varieties (Inpari 13, Inpari 31, Inpari 33, $\mathrm{RH}$, and PTB33) were fewer compared to TN1. FPLI value in TN1 was the highest among the tested rice varieties. Inpari 13 had better resistance to BPH compared to Inpari 31 and Inpari 33. In managing BPH in endemic areas, we recommend Inpari 13, Inpari 31, and Inpari 33 to be planted in rotation.
\end{abstract}

Key words: brown planthopper, modern rice varieties, pest management, resistance

\section{INTRODUCTION}

Brown planthopper (BPH), Nilaparvata lugens Stål (Hemiptera: Delpachidae), is one of the major insect pests of rice in Indonesia. The insect (both nymphs and adult) cause plant damage directly by sucking plant sap, affecting yellowing on leaves and wilting. Severe attack will cause mortality of the plant that commonly known as hopperburn symptom. BPH has also been reported can be a vector both of Rice grassy stunt virus and Rice ragged stunt virus (Cabauatan et al., 2009). It is widely understood that cultivating resistant variety is a valuable tool in integrated pest management because of its economic value, efficient, and environmentally friendly. Using resistant variety of rice can effectively decline BPH population in the field (Baehaki et al., 2011). Conversely, BPH can also adapt swiftly to the resistant varieties and developed as a new biotype that grows normally to the resistant variety as well as to the susceptible variety. In the endemic area, BPH populations are mostly a mixture of biotype 2 and biotype 3 , even the biotype 4 was indicated already emerged in the field (Baehaki \& Munawar, 2008).

In modern rice variety breeding programs, the purpose is not only to find a variety with high production but also tolerant to biotic and abiotic stress. Breeding program for development of $\mathrm{BPH}$ resistant variety is important to replace existing resistant variety which no longer resistance. Breeding of resistant variety with two or more resistance genes (major or minor resistance gen) could increase the durability of the variety in the field (Iswanto et al., 2015; Horgan, 2018). There are more than 70 resistance genes identified to rice planthopper, major gen and quantitatif trait loci (QTLs), however less than 10 resistance genes were used in breeding program (Fujita et al., 2012). The resistance genes were identified in local or wild rice. Some local rice varieties were identified as resistance and tolerance to the stress of biotic and abiotic factors as well as producing good quality of rice grain. Thirtynine resistant varieties developed from local paddy as their parental have been released (Sitaresmi et al., 2013; Sarao et al., 2016). Abdullah et al. (2008) utilized local and wild rice in crossing to find modern variety and rice lines with better performance in morphology and physiology.

Genetic resistance mechanism of plant varieties to insect are delivered through antixenosis, antibiosis and tolerance. Antixenosis is a mechanism that prevents the herbivores from laying egg or feeding initiation. Antibiosis is a way that plant varieties may harmful for the survival and growth of the herbivores. Tolerance is a capacity of a crop to produce high quantity and quality of yield even there is invasion of the herbivores (Smith, 
2005). The antixenosis and antibiosis mechanism of rice varieties to BHP can be evaluated by measuring the feeding, oviposition and functional plant loss index.

Since 1972, more than 200 rice varieties had been released by Ministry of Agriculture of Indonesia. The most recent rice varieties that have been reported to be resistant to BPH are Inpari 13 which was released in 2010 as well as Inpari 31 and Inpari 33 that were released in 2013 (Sasmita et al., 2019). However, response of the three above mentioned rice varieties to field population of BPH has not been fully understood. The aim of the study was to investigate resistance of those Inpari 13, Inpari 31, and Inpari 33 to BPH in the screen house.

\section{MATERIALS AND METHODS}

Research Site. The study was carried out in screen house and laboratory of Indonesian Center for Rice Research (ICRR) Sukamandi, Subang, West Java in December 2016 to June 2017.

Mass-rearing of the Brown Planthopper. The BPH population were collected from the rice field at Sukamandi, Subang, West Java (-6.356589, 107.643808). $\mathrm{BPH}$ was reared in the screen house and was maintained by continuous feeding by Ciherang variety. Thirty days old rice plant of Ciherang variety was cleaned and the dry sheath was removed, washed with tap water and planted in plastic pots which contain muddy soil. The plants were covered using a transparent plastic mylar (diameter $18 \mathrm{~cm}$; height $80 \mathrm{~cm}$ ). The upper part of the plastic mylar was closed with gauze to prevent the $\mathrm{BPH}$ escaped. Twenty-five female of BPH were transferred into the cage. The feeding plants were replaced in every 3-5 days. The $3^{\text {rd }}$ generation of BPHs was used for further study.

Rice Varieties. The rice varieties of Inpari 13, Inpari 31 , and Inpari 33 were used in this study. Some other rice varieties were also included in this study, namely Taichung Native1 (TN1) for susceptible check, Rathu Heenati (RH) and Potambi33 (PTB33) for the resistant check varieties. All seeds of tested varieties were achieved from the germplasm plant breeding division of ICRR. The study was performed using method described by Heinrichs et al. (1985) with some modifications.

Settling Behavior of Nymphs and Adults. The nymphs and adults of BPH were used in this test. The seeds of all the varieties were randomized sown about $10 \mathrm{~cm}$ apart each variety, with circular arrangement in a plastic pot (diameter $18 \mathrm{~cm}$; height $15 \mathrm{~cm}$ ) containing muddy soil (clay). Ten days after sowing, 48 of the $2^{\text {nd }}$ to $3^{\text {rd }}$ instar of BPH nymphs ( 8 individual/seedling) were infested on the tested seedling covered by plastic mylar cage (diameter $18 \mathrm{~cm}$; height $80 \mathrm{~cm}$ ). Another set was arranged for adults (female) with the same method as the nymphs. The settling insects were recorded at 2,6 , $12,24,48$, and 72 hour after infestation. The seedlings were disturbed by taping the plant after each count for reorientation of the insect.

Oviposition Test. The 14-days-old rice seedling of each varietiy was planted in plastic pot (diameter 18 $\mathrm{cm}$; height $15 \mathrm{~cm}$ ) containing muddy soil (clay) which was covered by mylar cage (diameter $18 \mathrm{~cm}$; height 80 $\mathrm{cm})$. Five gravid females (1-2 day old) were collected from colonies and infested to 30 days old seedling of each varietiy. The infested BPHs were allowed to feed and laid eggs for 5 days, after which the plants were collected and dissected under a stereo binocular microscope to count the eggs.

Functional Plant Loss Index (FPLI). The 14-daysold rice seedling of each variety was planted in the plastic pot (diameter $18 \mathrm{~cm}$; height $15 \mathrm{~cm}$ ) which were also covered by mylar cage (diameter $18 \mathrm{~cm}$; height $80 \mathrm{~cm}$ ). Thirteen days after planting, plants were covered with plastic mylar cage and then 25 nymphs ( $2^{\text {nd }}$ to $3^{\text {rd }}$ instar $)$ were released. Another set was arranged as control or uninfested plant. When susceptible check TN1 plants were wilting, insects of each variety were removed. All of the plants varieties were cut above the base and dried, oven-dried at $60^{\circ} \mathrm{C}$ for 48 hours. Uninfested plants were also dry and weighed. The FPLI value was calculated using formula (Heinrichs et al., 1985 ):

$$
\text { FPLI }=\left\{1-\left(\frac{a}{b}\right)\right\} \times 100 \%
$$

$$
\begin{array}{ll}
\text { FPLI } & \text { Functional Plant Loss Index } \\
\mathrm{a} & =\text { Dry weight of infested plant } \\
\mathrm{b} & =\text { Dry weight of uninfested plant }
\end{array}
$$

Data Analysis. The experiments were arranged using a completely randomized design and replicated 10 times for settling behavior of nymph and adult of BPH and 5 times for both of oviposition test and functional plant loss index. The data obtained were analyzed using analysis of variance with statistical tool for agricultural research (STAR) version 1.1.0. The data were 
transformed using log transformation and post hoc test using duncan multiple ranging test (DMRT) at $\alpha=0.05$.

\section{RESULTS AND DISCUSSION}

The settling of nymphs on rice varieties was not significantly different in every observation (Figure 1). There were different results for the adult (Figure 2). The number of adults observed in each rice varieties at 2, 6, and 12 hours after infestation (HAI) were not significantly different $(\mathrm{P}>0.05)$. After 24 hours, adults significantly settled on TN1 compared to Inpari 13, Inpari 33, RH and PTB33 (F= 5.52; $\mathrm{P}<0.001)$. Since 48 to 72 $\mathrm{HAI}$, number of adults in resistant varieties significantly less than $\mathrm{TN} 1(\mathrm{~F}=11.57 ; \mathrm{P}<0.001)$. Among modern rice varieties, the lowest number of adults was found in Inpari 13 than Inpari 31 and Inpari 33.
Gravid females laid more numbers of eggs on susceptible than resistant variety (Figure 3 ). The number of eggs in resistant varieties was significantly different than TN1 $(\mathrm{F}=10.74 ; \mathrm{P}<0.001)$. The lowest number was found in PTB33 (464 eggs) and the highest was observed in TN1 (1017 eggs), meanwhile the number of eggs found in Inpari 33, inpari 31, Inpari 13, and RH were $801,666,524$, and 584 , respectively.

FPLI value among tested varieties was significantly different $(\mathrm{F}=3.57 ; \mathrm{P}<0.005)$. FPLI value on TN1, Inpari 31 , and Inpari 33 were not significantly different, however Inpari 13, RH, and PTB33 were significantly lower than TN1. Meanwhile, Inpari 31, Inpari 33, Inpari 13, and RH showed the same FPLI value (Figure 4).

The result of settling test showed that nymphs were spread equally in each variety. At 2, 6, and 12

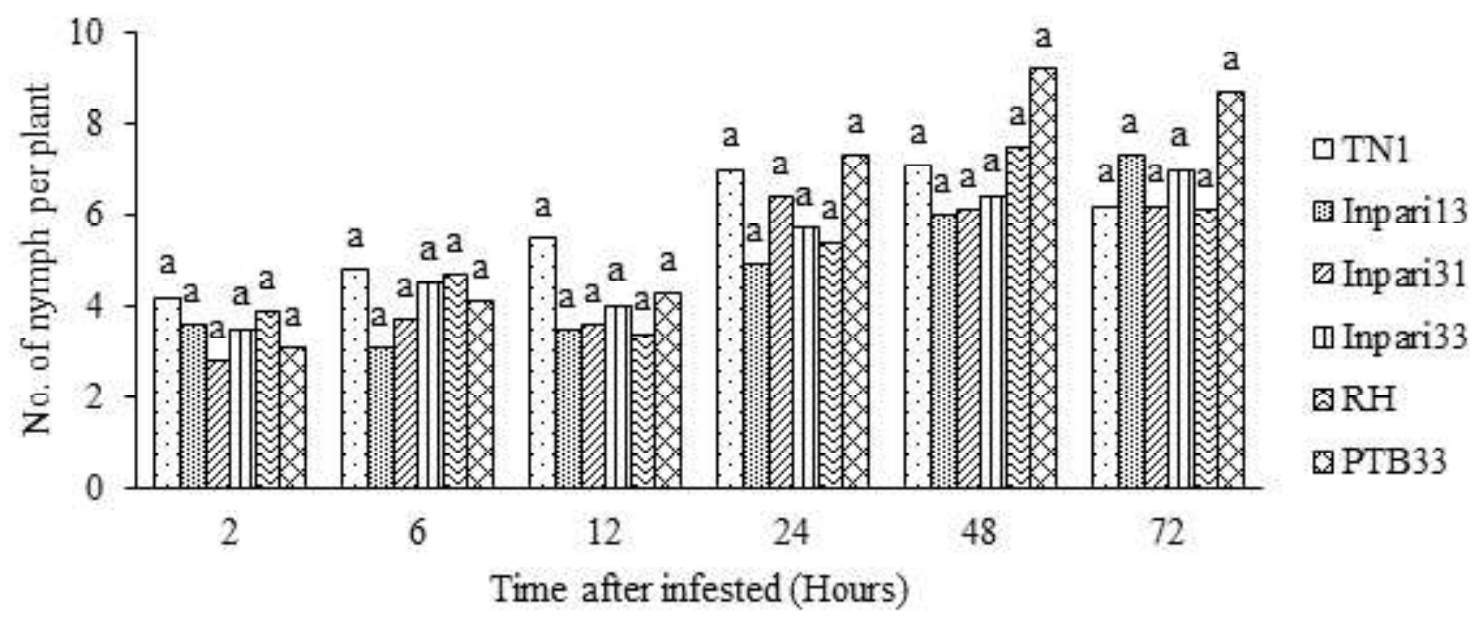

Figure 1. Preference of nymphs to settle on rice varieties. The bars followed by the same letter each time are not significantly different (DMRT; $\alpha=0.05)$.

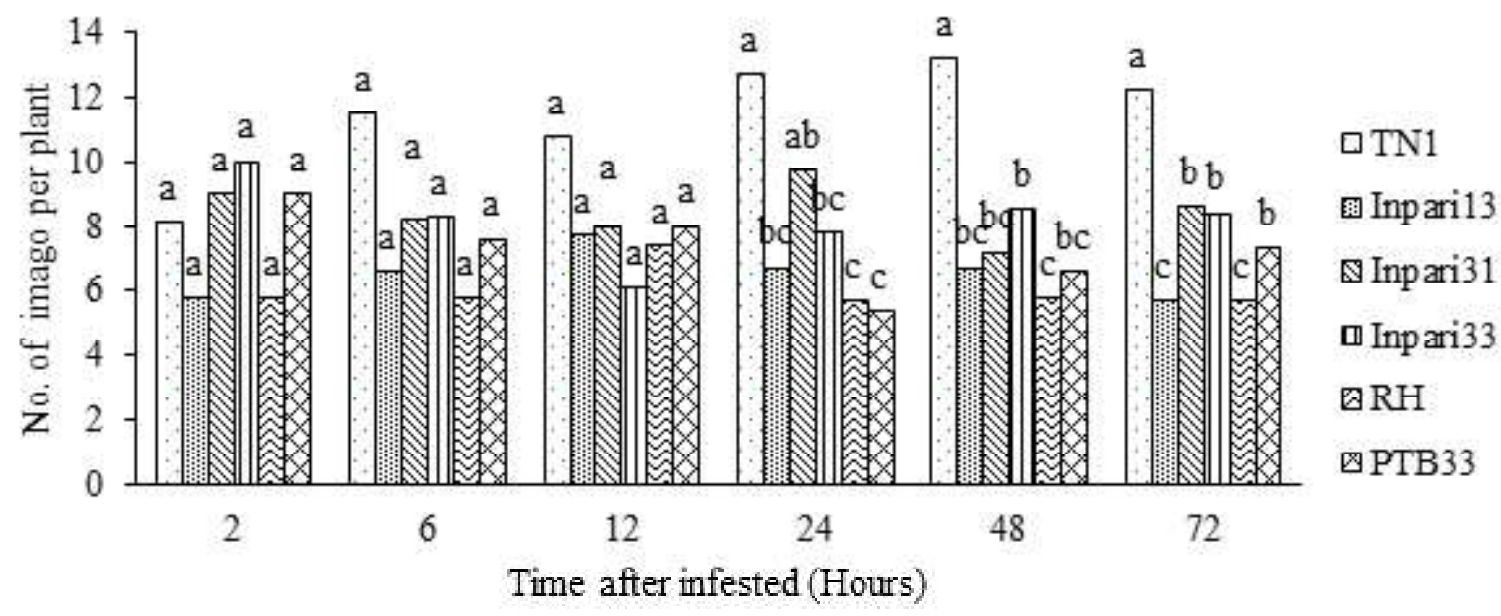

Figure 1. Preference of gravid females to settle on rice varieties. The bars followed by the same letter each time are not significantly different (DMRT; $\alpha=0.05)$. 
HAI, the nymphs which were settled on tested varieties were in the range of $44-50.6 \%$, and others nymphs were stayed on the soil and plastic mylar. At 24 hours after infestation, the settled nymphs on the tested varieties increased up to $76.5-88.1 \%$. It was suggested that the nymphs were sensitive to antixenosis released by the resistant varieties. Different result showed on the adults, all of them were settled on the tested varieties since the first observation. It means that the adults needed less time than nymphs to select or find the acceptance and suitability host.

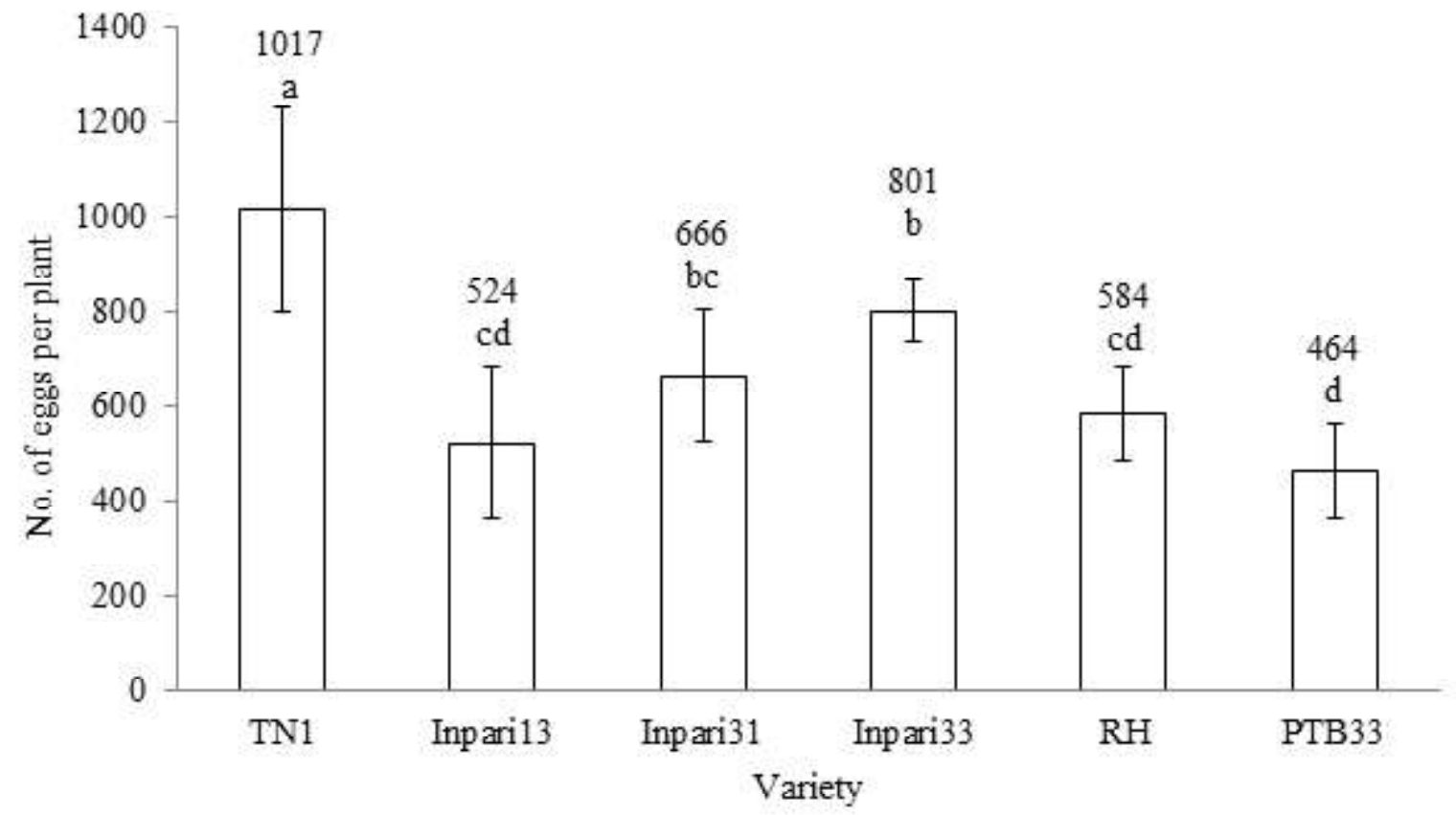

Figure 3. The number of eggs by five gravid females on each variety. Means followed by the same letter are not significantly different (DMRT; $\alpha=0.05)$.

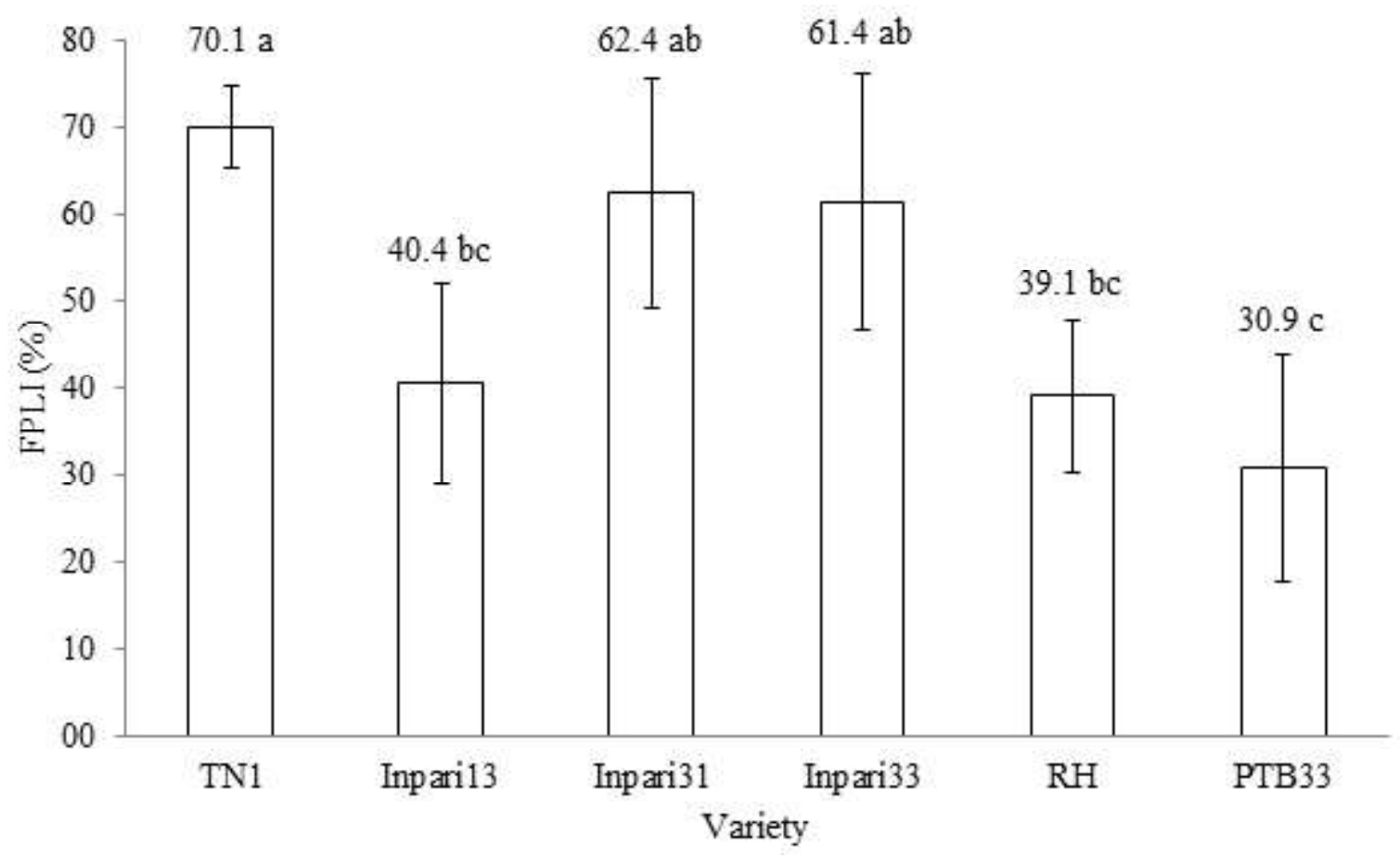

Figure 4. Function Plant Loss Index (FPLI) of each variety. Means followed by the same letter are not significantly different (DMRT; $\alpha=0.05)$. 
The adults of BPH will laid the eggs on the selected host, considering nutrition quality and the presence or absence of toxin within the host. The progeny seems to have more advantages for survival. It was demonstrated by the number of eggs on tested varieties by gravid females (Figure 3). FPLI values in susceptible varieties were higher than that of the resistant varieties. BPH has some differences in stylet penetration behavior on susceptible and resistant rice varieties. The total duration related to phloem sap ingestion was much shorter on resistant rice varieties than susceptible ones. BPH could feed easily on the phloem sap of the susceptible rice variety (Seo et al., 2010).

Resistant variety is an applicable technology that can be used by farmers for BPH management. It is important to focus on a breeding program constructing the rice which was resistant to BPH (Baehaki et al., 2011). Some differential varieties had been identified for their resistance genes and can be used as donors, namely Mudgo (Bph1), ASD7 (bph2), Rathu Heenati (Bph3 and Bph17), and PTB33 (bph2 and Bph3). Two resistant varieties (Bahbutong and Barumun) which were derived from PTB33 had been released by ICRR. IR64 had been known as resistant variety that had been widely used for BPH management for over 20 years after since its released in 1986. IR26 is a resistant variety containing Bph1 gene derived from Mudgo, meanwhile IR42 contains bph2 gene derived from ASD7. Both of the varieties were only survived from BPH in the field for 2-3 years after released. Cohen et al. (1997) reported that IR64 contained the Bph1 gene and some QTLs. Combination both of these major and minor genes were successfully prolong resistant durability in the field. Moreover, the IR64 had excellent cooking quality (Mackill \& Khush, 2018). Resistant varieties will lose their resistance as they are continually exposed to high $\mathrm{BPH}$ densities as well as in conditions which are favorable for BPH such as low number of predator or parasitoid and high input of nitrogen fertilizer. Within this condition, the BPH can rapidly be adapted to the host, which is now occurred in many intensive rice production areas in Indonesia.

Inhibition of growth population generally is derived from the morphological characteristic and biochemical within plant which affects the behavior or the metabolism of insect. The physical factors such as trichome become obstacle for BPH to invade the host plant. On resistant varieties, trichomes were tighter, more abundance, larger and longer though there was no correlation between trichome morphology and resistance level to BPH (Horgan, 2009; Astuti et al., 2012). Resistant plant contains secondary metabolites that play a role as feeding excitants or inhibitor or toxin. Secondary metabolites are substance which are produced by the plants as defense chemicals. They are not required for normal growth and development. Their absence does not cause negative effects to the plant. Antixenosis and antibiosis characters in resistant variety will influence BPH population. Some studies showed that BPH had no preferred to resistant varieties (IR74 and PTB33) and feeding more on susceptible than resistant varieties (Rahmini et al., 2012). Imago of BPH were more settled, fed and laid their eggs in susceptible variety than resistant variety (Suprihanto et al., 2016).

Recent resistant varieties which had been released were Inpari 13, Inpari 31, and Inpari 33. Inpari 13 (released in 2010) was an introduction from International Rice Research Institute (2014) with selection number OM1490, originated from crossing of OM606/IR18348-36-3-3. The Inpari 31 was originated from crossing of pepe/BP342B-MR-1-3-KN-1-2-3-6MR-3-BT-1, while Inpari 33 was originated from crossing of BP360E-MR-79-PN-2/IR71218-38-4-3// BP360E-MR-79-PN-2 (Sasmita et al., 2019). Among these varieties, only Inpari 13 contained Bph1 and Bph3 genes (Damayanti \& Utami, 2014). Bph3 was a resistance gene that widely used as donors, this gene was still effective to suppress population of BPH in the field in many countries (Horgan et al., 2015). The result showed that Inpari 13, Inpari 31, and Inpari 33 were resistant to BPH obtained from Subang, West Java. Inpari 13 produced high level of resistance compared to Inpari 31 and Inpari 33. Combination of synchronously planting and resistant variety were successfully suppressed the BPH invasion in Klaten, Central Java (Baehaki, 2014).

$\mathrm{BPH}$ is r-strategist insect that can reproduce rapidly, they have a short generation time and quickly adapted on their host plant. The adaptation capability of $\mathrm{BPH}$ was suggested caused by bacterial endosymbionts and yeasts that involved in insect nutrition. A wide range of endosymbionts had been associated with feeding capacity in BPH (Ferrater et al., 2015; Horgan et al., 2019). Resistant variety management is necessary and important to perform for extending effectiveness of the released varieties in the field (Horgan, 2018). Once variety (genes) rotation were properly conducted, the $\mathrm{BPH}$ will difficult to adapt to the host. Although Inpari 31 and Inpari 33 had lower level of resistance to $\mathrm{BPH}$ than Inpari 13, these varieties could be used in variety rotation program which was should not be cultivated simultaneously in BPH endemic area. Horgan et al., (2015) examined the virulence of 12 planthopper populations from across South (6 populations) and South 
East (6 population) Asia on resistant, tolerant and susceptible varieties. There were two apparent groups, Indonesian population (Subang, West Java) was similar with Vietnam, Philippines, China, and Taiwan population but different with India (Hyderabad and Lludhiana) and Bangladesh populations.

According to the results, resistance level of Inpari 13, Inpari 31, and Inpari 33 were under RH and PTB33. In practice, we recommended to add another tool of BPH management to enhance the resistance, especially in culture practice. In the field, rice culture practices also influence the BPH host-adaptation capability. Some research results reported that nitrogen excess would decrease the plant resistance and increase the $\mathrm{BPH}$ fitness (Lu et al., 2004; Rashid et al., 2016; Horgan et al., 2018). Thus, a leaf color chart for nitrogen fertilizer dosage should be used by the farmers. The use of nitrogen dosage should be adjusted to the plant needs. On the other hand, silicate had been reported can be a trigger to enhance plant resistance to $\mathrm{BPH}(\mathrm{Wu}$ et al., 2017). Flowering plants as refuge were planted to improve the role of parasitods in BPH management (Sinulingga et al., 2019). Resistant varieties require proper nutrient management to reduce BPH adaptation capability. Cultivating pattern will also influence development of BPH. The availability of rice plant all year around, will cause accumulation of BPH population. The BPH was already in high population since it was in seedbed or vegetative stage, which resulted in an increase of adapted BPH in rice plant and the outbreaks will occur rapidly.

\section{CONCLUSION}

BPHs showed lower level on settle preference and number of laid eggs on Inpari 13, Inpari 31, Inpari 33, Rathu Heenati (RH), and Potambi33 (PTB33) than TN1. The functional plant loss index value in TN1 was the highest compared to the other rice varieties. Among recent rice resistant varieties, Inpari 13 produced better resistant capability to BPH obtained from Subang, West Java. Generally, RH and PTB33 showed higher level resistance than the other varieties. Inpari 13, Inpari 31, and Inpari 33 can be cultivated as an alternative in rotation rice varieties management.

\section{ACKNOWLEDGMENTS}

The authors thank Nono Sumaryono and Endang Data for their technical assistance during this study.

\section{REFERENCES}

Abdullah B, Tjokrowidjojo S, \& Sularjo. 2008. Perkembangan dan prospek perakitan padi tipe baru di Indonesia. Jurnal Litbang Pertanian. 27(1): 1-9.

Astuti P, Supriyadi, \& Supriyono. 2012. Karakterisasi fenotip kultivar padi tahan dan rentan wereng coklat, Nilaparvata lugens Stål. (Hemiptera : Delpachidae). JEI. 9(2): 57-63.

Baehaki SE, Arifin K, \& Munawar D. 2011. Peran varietas tahan dalam menurunkan populasi wereng coklat biotipe 4 pada tanaman padi. Penelitian Pertanian Tanaman Pangan. 30(3): 145-153.

Baehaki SE \& Munawar D. 2008. Identifikasi biotipe wereng coklat di Jawa, Sumatera dan Sulawesi dan reaksi ketahanan kultivar padi. In: Suprihatno B, Daradjat AA, Suharto H, Toha HM, Setiyono A, Suprihanto, \& Yahya AS (Eds.). Prosiding Seminar Apresiasi Hasil Penelitian Padi Menunjang P2BN. pp. 347-359. Balai Besar Penelitian Tanaman Padi, Jawa Barat, Indonesia.

Baehaki SE. 2014. Budi Daya Tanam Padi Berjamaah Suatu Upaya Meredam Ledakan Hama dan Penyakit dalam Rangka Swasembada Beras Berkelanjutan. Edisi 2. Balai Besar Penelitian Tanaman Padi. Subang, Jawa Barat.

Cabauatan PQ, Cabunagan RC, \& Choi IR. 2009. Rice viruses transmitted by the brown planthopper Nilaparvata lugens Stal. In: Heong KL \& Hardy B (Eds.). Planthoppers: New Threats to the Sustainability of Intensive Rice Production Systems in Asia. pp. 357-368. International Rice Research Institute, Philippines.

Cohen MB, Alam SN, Medina EB, \& Bernal CC. 1997. Brown planthopper, Nilaparvata lugens, resistance in rice cultivar IR64: mechanism and role in successful $N$. lugens management in Central Luzon, Philippines. Entomol. Exp. Appl. 85(3): 221-229.

Damayanti D \& Utami DW. 2014. Pendugaan gen Bph1, bph2, Bph3 dan bph4 pada galur-galur padi terpilih tahan hama wereng batang cokelat 
(Nilaparvata lugens [Stål]). Jurnal AgroBiogen. 10(1): 1-8.

Fujita D, Kohli A, \& Horgan FG. 2012. Rice resistance to planthoppers and leafhoppers. Crit. Rev. Plant Sci. 32(3): 162-191.

Ferrater JB, Naredo AI, Almazan MLP, de Jong PW, Dicke M, \& Horgan FG. 2015. Varied responses by yeast-like symbionts during virulence adaptation in a monophagous phloem-feeding insect. Arthropod Plant Interact. 9(3): 215-224.

Heinrichs EA, Medrano FG, \& Rapusas HR. 1985. Genetic Evaluation for Insect Resistance in Rice. International Rice Research Institute. Los Bannos, Philippines.

Horgan FG, Ramal AF, Bentur JS, Kumar R, Bhanu KV, Sarao PS, Iswanto EH, Chien HV, Phyu MH, Bernal CC, Almazan MLP, Alam MZ, Lu Z, \& Huang SH. 2015. Virulence of brown planthopper (Nilaparvata lugens) populations from South and South East Asia against resistant rice varieties. Crop Prot. 78: 222-231.

Horgan FG. 2009. Mechanisms of resistance: a major gap in understanding planthopper-rice interactions. In: Heong KL \& Hardy B (Eds.). Planthoppers: New Threats to the Sustainability of Intensive Rice Production Systems in Asia. pp. 281-302. International Rice Research Institute, Philippines.

Horgan FG, Srinivasan TS, Crisol-Martínez E, Almazan MLP, Ramal AF, Oliva R, Quibod IL, \& Bernal CC. 2019. Microbiome responses during virulence adaptation by a phloem-feeding insect to resistant near-isogenic rice lines. Ecol. Evol. 9(20): 1191111929.

Horgan FG. 2018. Integrating gen deployment and crop management for improved rice resistance to Asian planthoppers. Crop Prot. 110: 21-33.

Horgan FG, Cruz AP, Bernal CC, Ramal AF, Almazan MLP, \& Wilby A. 2018. Resistance and tolerance to the brown planthopper, Nilaparvata lugens (Stål), in rice infested at different growth stages across a gradient of nitrogen applications. Field Crops Res. 217: 53-65.

International Rice Research Institute (IRRI). 2014. Standard Evaluation System for Rice. 5th edition. International Rice Research Institute. Los Bannos, Philippines.
Iswanto EH, Susanto U, \& Jamil A. 2015. Perkembangan dan tantangan perakitan varietas tahan dalam pengendalian wereng coklat di Indonesia. Jurnal Litbang Pertanian 34(4): 187193.

Lu ZX, Heong KL, Yu XP, \& Hu C. 2004. Effects of plant nitrogen on ecological fitness of the brown planthopper, Nilaparvata lugens Stål. in rice. J. Asia-Pac. Entomol. 7(1): 97-104.

Mackill DJ \& Khush GS. 2018. IR64: a high-quality and high-yielding mega variety. Rice 11: 18.

Rahmini, Hidayat P, Ratna ES, Winasa IW, \& Manuwoto S. 2012. Respons biologi wereng batang coklat terhadap biokimia tanaman padi. Penelitian Pertanian Tanaman Pangan. 31(2): 117-123.

Rashid MM, Jahan M, \& Islam KS. 2016. Impact of nitrogen, phosphorus and potassium on brown planthopper and tolerance of its host rice plants. Rice Science. 23(3): 119-131.

Sarao PS, Sahi GK, Neelam K, Mangat GS, Patra BC, $\&$ Singh K. 2016. Donors for resistance to brown planthopper Nilaparvata lugens (Stål) from wild rice species. Rice Sci. 23(4): 219-224.

Sasmita P, Satoto, Rahmini, Agustiani N, Handoko DD, Suprihanto, Guswara A, \& Suharna. 2019. Deskripsi Varietas Unggul Baru Padi. Badan Penelitian dan Pengembangan Pertanian, Jakarta.

Seo BY, Jung JK, Choi BR, Park HM, Lee SW, \& Lee BH. 2010. Survival rate and stylet penetration behavior of current Korean population of the brown planthopper, Nilaparvata lugens, on resistant rice varieties. J. Asia-Pac. Entomol. 13(1): $1-7$.

Sinulingga NGH, Trisyono YA, Martono E, \& Hadi B. 2019. Benefits of flowering plants as refuge to improve the ecosystem services by egg parasitoids of the rice brown planthopper. JPTI. 23(1): 68-74.

Sitaresmi T, Wening RH, Rahmi AT, Yunani N, \& Susanto U. 2013. Pemanfaatan plasma nutfah padi varietas lokal dalam perakitan varietas unggul. Iptek Tanaman Pangan. 8(1): 22-30.

Smith CM. 2005. Plant Resistance to ArthropodsMolecular and Conventional Approaches Springer, Netherlands. 
Suprihanto, Somowiyarjo S, Hartono S, \& Trisyono AY. 2016. Preferensi wereng batang cokelat terhadap varietas padi dan ketahanan varietas padi terhadap virus kerdil hampa. Penelitian Pertanian Tanaman Pangan. 35(1): 1-8.
Wu X, Yu Y, Baerson SR, Song Y, Liang G, Ding C, Niu J, Pan Z, \& Zeng R. 2017. Interactions between nitrogen and silicon in rice and their effects on resistance toward the brown planthopper Nilaparvata lugens. Front. Plant Sci. 8: 28. 